\title{
都市河川，運河が周辺市街地の熱環境に及ぼす効果 \\ The Cooling Effect of the River and the Canal on the Micro-climate in Urban Area
}

营 和利“，河原能久”

By Kazutoshi KAN and Yoshihisa KAWAHARA

\begin{abstract}
To evaluate the effect of river and canal on thermal environment, we performed the field observation at the Tama River and the Shibaura Canal. The detailed measurement of vertical temperature distribution within the river and the canal and measurement of urban temperature along the street crossing the river and the canal were carried out and horizontal extent of cooling effect were confirmed by these observation. In the Tama River, the cooling effect is restricted in day time, while in the Shibaura Canal, this cooling effect appeared in night time.

Keyword:thermal environment, cooling effect, urbanization
\end{abstract}

1.はじめに

都市の中に残されたオープンスペースとしての河川, 運河は貴重な親水空間であり, 都市化の進展の激し い地域においては総合的な整備の対象として注目されている。河川に近い地域では夏季の凉しい風を享受で き,また郊外は都心に比べて数度の気温の低下が見られるなど, 熱環境は都市の構造, 緑, 水域の存在によ つて強く影響されている。人口エネルギーの消費が集中する東京のような都市においては, 舗装面積の増加 す相まってヒートアイランド現象が出現し, 夏季の熱帯夜の継続日数を増加させるなど, 熱環境は悪化して いる。都市の中に残された水域に海風を呼び込める都市河川は, 水空間の視覚的, 心理的効果に加えて, 夏 季の冷源としての働きを有しており，広い河道空間を吹く風によって周辺地域の気温緩和をるたらすことが 観測によって指摘されている。著者らが行った河川周辺の気温分布の测定によっても，河道付近では気温が 低い結果を得ており, 熱㻴境への河川の効果を示している。しかし，この効果は周辺部の地形，都市構造に 影響されており，従来の観測においても必ずしも十分な観測データが蓄積されているとは言えない。 都市の中に残された水域の微気象への効果を積極的に評価し，これを都市環境の改善の方策に生かせるため

\footnotetext{
* 正会員 芝浦工業大学助教授 工学部土木工学科

（T108 東京都港区芝浦3-9-14）

** 正会員 工博 東京大学助教授 工学部土木工学科

（T113 東京都文京区本郷7-3-1）
} 
には，色々なタイプの水域での熱的効果を定量的に評価する事が必要である。

本研究では水域が周辺市街地の夏季微気象に及ぼす効果を現地観測によって定量的に評価するために 2 種 類の気温観測を行った。

(1)周辺部の気温に与える水域の効果を把握するために，河道のすぐそばまで住宅地が密集している河川鶴見 川と，ビル街の中に掘り込み河川のような芝浦運河を対象に，周辺部での気温分布を測定した。

(2)冷源として働く水面, 高水敷の効果を評価するために河道横断内の温度分布測定を実施した。広い高水敷 と自然河川の様相を多く残している多摩川と, また芝浦運河で運河に沿って公園が整備された地点とを対象 に行った。

いずれの観測す 24 時間実施し, 水域の効果の時間変化について検討を行った。

\section{2. 現地観測の概要}

鶴見川流域での面的な観测では, 道路網を利用して数ルートを 4 台の自動車で移動しながら, 車に固定し たサミスター温度計により定点観測を行った。発砲スチロール製の円筒内にセンサー部を固定し，日射を遮 蔽して, 自動車のルーフから突き出した棒に固定し, 各点 1 時間間隔で测定した。芝浦運河の测定では, 自 転車による移動定点観測を行った。鶴見川と同様のセンサーを用い, 地上から0. $5 \mathrm{~m}$ と $1.5 \mathrm{~m}$ の高さで気温を測 定した。

多摩川での河道内と芝浦運河の断面内の鈶直温度分布は上記の遮蔽円筒サミスター温度計を塩ビパイプに 固定し, 橋の上から吊して移動しながら測定をした。測定点の高さは水面あるいは高水敷から0. $3 \mathrm{~m}, 0.8 \mathrm{~m}$, $1.5 \mathrm{~m}, 2.5 \mathrm{~m}, 3.5 \mathrm{~m}, 4.5 \mathrm{~m}, 5.5 \mathrm{~m}, 6.5 \mathrm{~m}$ とし, 多摩川では河道内20測線, 芝浦運河では22測線での測定を行っ た。多摩川の観測地点は河口から $10.5 \mathrm{~km}$ 感潮区間にあり, 潮汐と共に橋からの距離が変化するが, 平均約 $11 \mathrm{~m}$ ったために水面から橋の高さまでは測定出来なかった。高水敷上では地上 $0.3 \mathrm{~m}$ ら橋の高さまで測定が 可能であった。河道内の測定に併せて橋上 $0.5 \mathrm{~m}$ と $2.0 \mathrm{~m}$ 高さでも同時に測定を行った。さらに河道の影響範 囲を测定するために橋に沿った道路での定点観測を同時に行った。測定間隔は 3 時間とし 24 時間観測した。 運河の测定は運河に沿って階段護岸, 公園が整備されている区間の橋を利用して運河部分の測定を行った。 また，運河部分以外は塩ビ管を鉊直に立てて测定を行った。

運河の観測では赤外線熱画像装置（日本アビオニクス TVS-2000ST）を用いて地表面，道路面の温度分布を あ測定した。またこの気温测定とは別に, 多摩川高水敷の整備に伴う地表温度の変化を熱画像で測定した。

これらの一連の現地観測は, 色々なタイプの水域の熱的効果の測定結果を比較することにより, 今後の水 域の整備の在り方への資料を提供する事を目的としている。ここでは紙面の都合で, 冷源とし働く水面, 高 水敷の効果を测定した河道内，運河内の鈶直気温分布についての結果を示すこととする。

\section{3. 観測結果}

(1) 河道, 運河断面内の気温分布

冷源として働くであろう河道内の温度分布についてまず検討する。観測日の1992年9月2日，3日は終日強い 海風が河道に沿って吹いていた。図ー1 は多摩川での日中, 夜間の代表的な温度分布を示したものである。 13 時の温度分布によると低水路部分はほぼ一様な分布をし, 高水敷, 水際では温度勾配が急で複雑な形をし ている。他方夜間は高水敷も含めて河道内はほぼ一様な分布をしている。日中, 夜間での平均の効果を見る ために，5〜17時を日中平均，19〜3時を夜間平均として温度分布を示したのが図一 2 である。図一 2 は橋に 沿って600m市街地に入った地点での気温を市街地気温の代表値（ $\mathrm{T}_{\mathrm{s}}$ ）と仮定し，この気温との偏差 $\mathrm{T}-\mathrm{T} s$ の気温コンタを示したすのである。日中平均での河道内低水路部分の水面に近い領域での気温は周辺市街地 


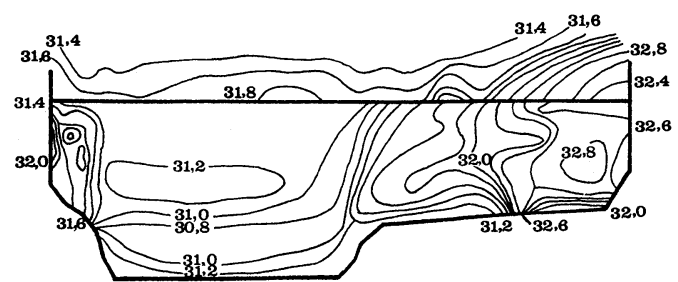

図-1（a）多摩川気温分布（13時）

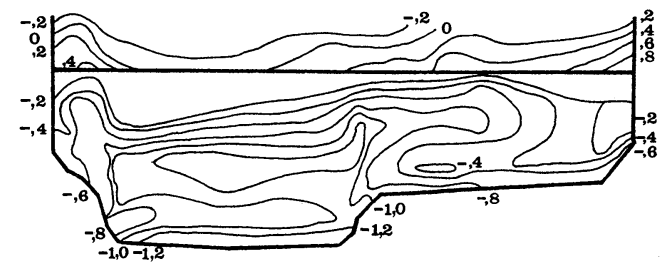

図一 2 (a) 市街地気温との偏差 (日中平均)

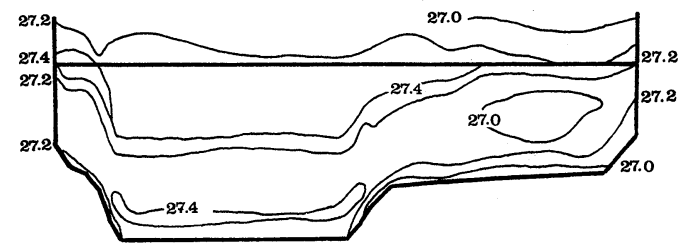

図-1(b) 多摩川気温分布（0時）

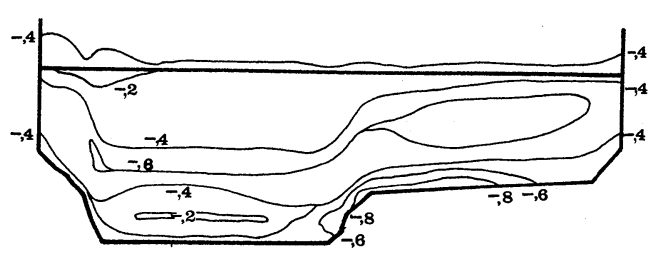

図-2(b) 市街地気温との偏差（夜間平均） に比べて $1.2 \sim 0.8^{\circ} \mathrm{C}$ 低く, 高水敷です $0.8 \sim 0.4^{\circ} \mathrm{C}$ 低く, 河道内全体が市街地より低温である。このように 河道内の気温は市街地に比べて低く, 冷源として作用していることが分かる。また夜間平均では日中平均ほ ぞの低温効果は見られず, 特に低水路部分の気温と市街地との気温差が小さくなり, むしろ高水敷の地表近 くに低温部分が広く存在し, 冷源としての効果が大きい。一日平均においても河道内は $0.8 \sim 0.2^{\circ} \mathrm{C}$ 低かった。 次に芝浦運河での日中平均の気温分布を示したのが 図ー 3 である。図- 4 は運河にかかる橋の中央, 橋上 $2.0 \mathrm{~m}$ の地点の気温 $\mathrm{T}_{\mathrm{bs}}$ との偏差 $\mathrm{T}-\mathrm{T}_{\mathrm{bs}}$ の日中, 夜 間平均を示したすのであるが，日中は運河部分とそれ に隣接する公園, 道路部分都では気温が大きく異なる ことを示している。運河部分は橋上気温に比べて低い が，公園部分は高く，水域の効果よりあ地表面温度に 支配されていることを示している。観測日の1992年9月 4 日，5日に風が弱かったことがこの結果となった一因 と思われる。水際の階段護岸の部分が高温であったの は意外であった。タイルを張った構造は景観的には優

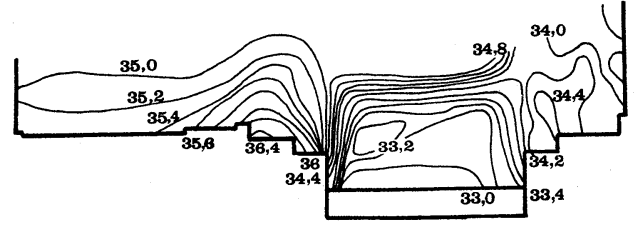

図-3 芝浦運河気温分布（日中平均）

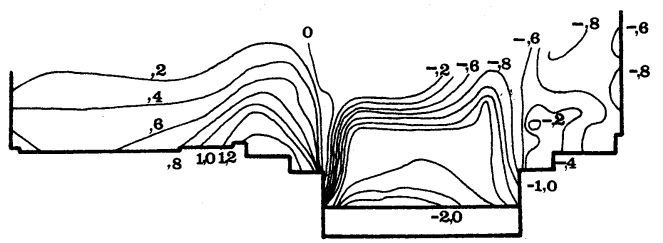
れているが，熱環境的には劣っていることを示してい 図ー4（a）橋上と運河内との気温偏差（日中平均） る。夜間には一様分布に近くなる。

広い高水敷と海風の通り道となる多摩川と比べ, 都 市内のビルに囲まれた運河では海風を呼び込む能力が 低いが, 冷源としての効果を有している。しかし，こ の効果は運河に近接した領域に限られそうである。

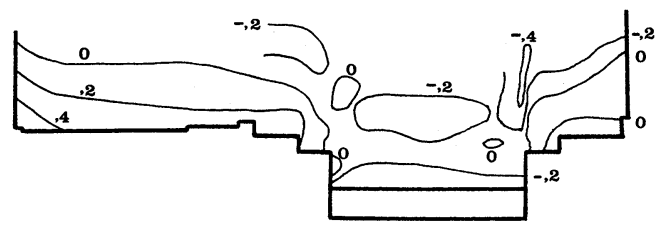

図-4（b）橋上と運河内との気温偏差（夜間平均）

(2) 河道内気温の構造

多摩川, 芝浦運河にかかる橋中央地点での鉛直温度分布の時間変化を示したのが図一 5 である。上段は各 高さでの気温の橋上気温 T bs からの偏差を示し, 下段は水面温度 Tws - T bsを示したすのである。図中のム の記号は負の偏差を表わし，三角形が大きいほど橋上気温からの偏差が大きいことを示している。多摩川， 芝浦運河共に, 水面温度が橋上気温に比べて低くなるに従って鉿直気温分布す橋上気温より低くなることを 示している。芝浦運河の方が水面温度と橋上気温との偏差が大きく, それに従って運河内気温は水面温度の 
偏差が逆転する夜間以 外は低温を示している。 また, 多摩川の高水敷 での同様な分布を示し たのが図ー6(a)であ る。高水敷の気温む水 温の変化につれて同様 な変化を示している。 他方芝浦運河に沿った 公園での分布を示した 図ー6(b)では, 気温 の変化は水面温度の変 化に追随しておらず， 公園には運河の熱的効 果が直接作用していな いことを示している。 水面温度, 水面直上の 気温, 橋上気温の相関 を見るため $\mathrm{T}_{W S}-\mathrm{T}_{\mathrm{bS}}$ 横軸に, $\mathrm{T}_{0.3}-\mathrm{T}_{\mathrm{bs}}$ を縦軸にして各時刻の データをプロットしたのが図ー7である。図中 ○は日中，夜間を表わしている。多摩川の 場合には, 水面温度と橋上気温との偏差が $2^{\circ} \mathrm{C}$ を越えるまでは水面直上の気温の変化が出現し ないが，この值を越えると水温の低下と共に直 上の気温が低下し，水面の冷塬としての効果を 示している。他方, 芝浦運河では水温の变化に 直上の気温が直接対応して変化している。高水 敷, 運河沿い公園での同様な整理を図ー7 (b), (d)に示した。この図では綎軸が地表面上 $0.3 \mathrm{~m}$ の地点の気温と橋上気温との偏差である。多摩 川高水敷では低水路と同様な結果が得られたが， 運河沿い公園では全く異なっていた。これは前 述したように, 水温偏差の大きくなる日中に公 園のタイルが高温になるためである。

（3）冷源としての市街地への効果

水面温度の変化に伴って水面, 地表近くの気 温が変化することが分かったが, この冷源効果

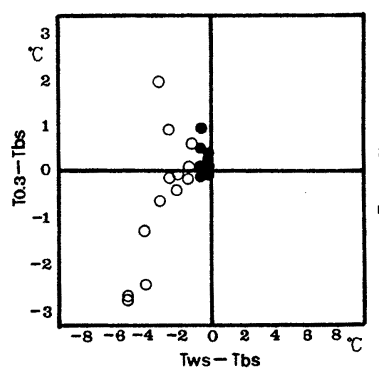

(a) 多摩川低水路部分

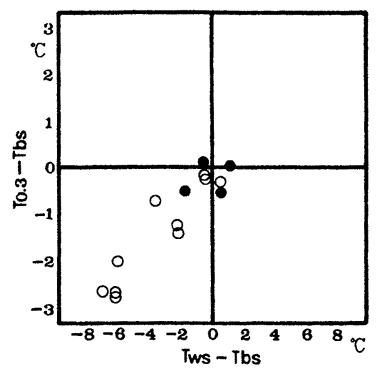

(c) 芝浦運河水路部分

図-7 水面温度と直上気温との相関 が堤防を越えて市街地にどの程度影響しているかを梌討するために, 橋上中心 $2 \mathrm{~m} の$ 高さの気温と市街地気温 との偏差の日変化を示したのが図ー8である。多摩川では橋上を通って吹いている風の温度は終日市街地に 
比べて低温で, 河川の冷源効果が風によって市街地に運ばれてい ることが分かる。この効果は強い海風の吹く日中の方が弱い陸風 の吹く夜間に比べて相対的に大きくなることを示している。芝浦 運河では卓越した海風は観測されず風が弱かったために, 橋上が 周辺に比べて卓越的な低温には成らなかった。図ー7 (c) に見られ るように運河も冷源としての効果を有しているが, その効果が橋 の上まで及ばなかったのは風が弱かった為と思われる。このよう に冷源効果が市街地にまで及ぶためには風の存在が重要であり, 市街地に海風を導く都市構造の重要性を示している。図ー8 と同 様の内容を視点を変えて見たのが図ー9である。横軸は市街地気 温と水面温度との偏差で, 綐軸は橋上 $2 \mathrm{~m} の$ 気温と市街地気温との 偏差を示したすのである。多摩川の結果では, 市街地気温が水面 温度に比べて低温の場合には, 橋上の気温が市街地温度に比べて

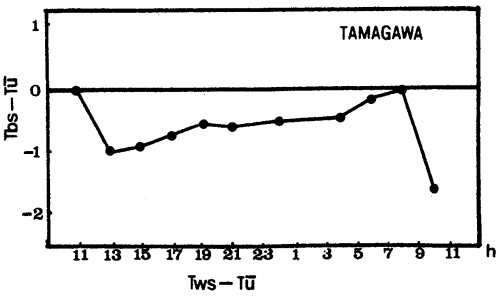

(a) 多摩川

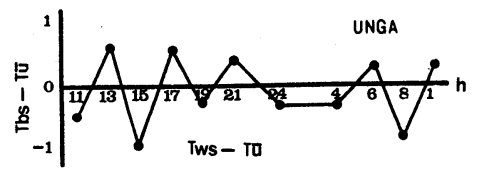

（b）芝浦運河

図-8 橋上気温と市街地気温の偏差 低いことを示しているが，芝浦運河では水面温度の偏差と橋上気 温との相関が低く, 市街地への冷源効果 の影響が低いことを示している。図ー1 0 は赤外線熱画像装置で測定した日中と 夜間での運河と周辺の表面温度の横断分 布を示したものであるが, 日中には公園 のタイル部分が高温で, 気温が地表面温 度に支配されていることを示している。 また，夜間には大きな天空率による放射 冷却によりこの部分の温度低下が大きく， 横断的に一様化している。

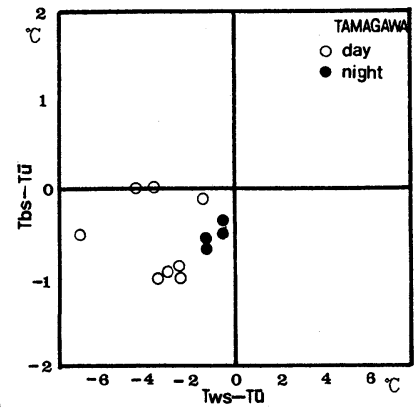

図 -9

橋上気温と水面温度の相関

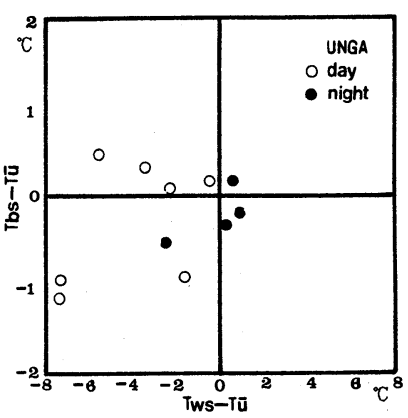

(b) 運河
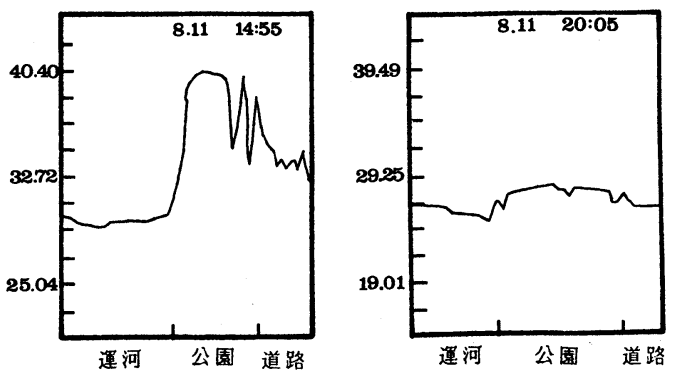

図-10 運河での表面温度（赤外線熱画像） で移動しながら定点で気温を测定した。日中平均, 夜 間平均の各定点での気温を示したのが図-11，12である。多摩川日中平均では, 左岸, 右岸の交差点で は周辺より気温が高くなっている。左岸側の道路は歩道に木が植わっており，各測点は木陰に位置するため に右岸に比べて低温であるが，河川に近づくに従って気温が低下している様子が知られる。日中は河川から 市街地に向かって風が吹いており，河川の影響は湘定範囲の600 m以遠にまで及んでいた。他方，右岸側は風 が河川に向かって吹いていたために, 河川の冷源効果が伝わっていない結果となっている。運河では公園部 分の高温が目だち，冷源効果はこの部分には影響していない。夜間平均での同様な効果を示した図一 12 に よると, 多摩川では冷源効果の市街地への効果は低くなり, 影響範囲す河川にごく近い200mの範囲に限定さ れている。これは夜間の弱い陸風と, 市街地気温と水面温度の偏差の減少によるものと思われる。他方, 芝 浦運河では日中とは反対に公園部分の気温が低下し，公園部分に冷源効果の影響がみられる。 

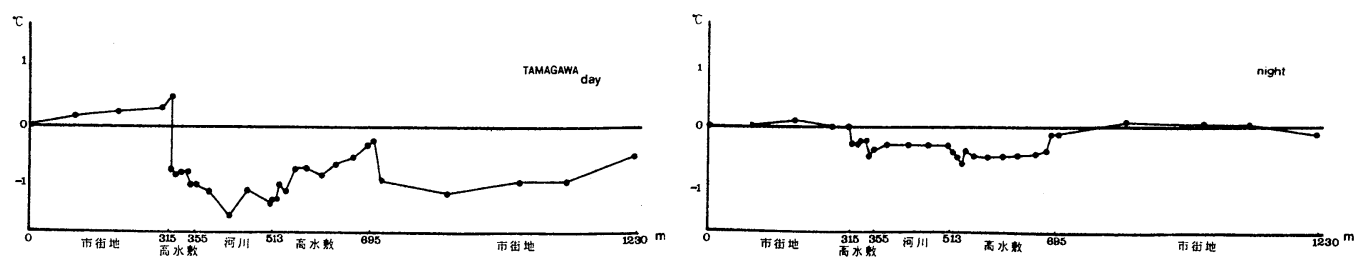

図－1 1 市街地との気温偏差の横断変化 (多摩川)

(a) 日中平均

(b)夜間平均

4. 結論

河川，運河の有する夏期の冷 源としての効果を定量的に把握 することを目的として，タイプ

の違う水域である高水敷の広い 多摩川とビル街に残され運河に
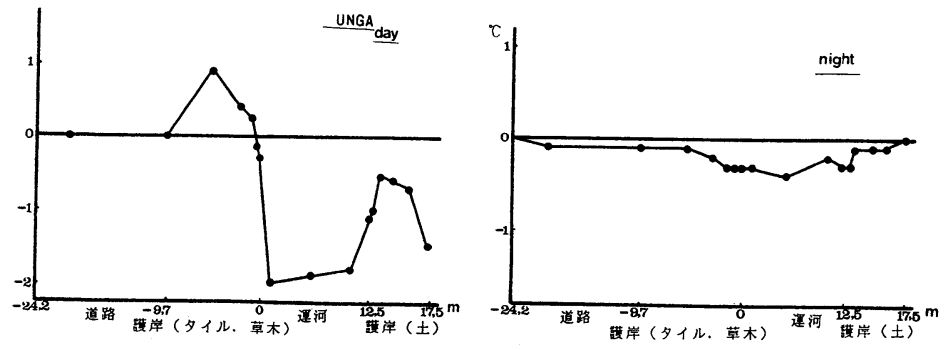
おいて気温の鉛直分布, 熱画像

図-12 気温偏差の横断変化（芝浦運河）

(a) 日中平均

(b) 夜間平均 の測定を行った。その結果として以下のことが得られた。

1) 高水敷の広い多摩川の河道内気温の日中, 夜間それぞれの平均は市街地気温に比べて低く, 河川が市街地 に対して冷源として働いている。この効果は海風の影響を強く受けている。

2) ビル街の芝浦運河です運河内は周辺に比べて気温が低いが, 海風の効果が小さく, 日中は水際を離れると すぐに高温になり影響範囲が運河内に限られていた。

3)多摩川, 芝浦運河ともに水面温度, 水面直上 $0.3 \mathrm{~m}$ の気温の橋上気温からの偏差は正の相関を示しており, 水面が冷源として作用していると判断できる。高水敷上0. $3 \mathrm{~m}$ の地点の気温と水面温度との関係も同様に正の 相関を示した。

4) 水面の冷源効果は水面温度から, 河道内, 橋上, 市街地の気温へと影響が伝播しており, その効果の強さ は海風の強さ，風向に大きく影輹される。

$5)$ 運河では運河沿いの公園のタイル部分の気温が高く，日中の冷源効果が見かけ上消隇していた。

6)多摩川では冷源効果が市街地に及ぶのは日中に限られ, 河川からの風を受ける市街地方向では道に沿って $600 \mathrm{~m}$ 以遠まで効果が及んでいた。芝浦運河では夜間にのみ冷源効果が見られ，その影響範囲は運河沿いの公 園部分に限られていた。

謝辞 現地観湘では園部, 甲斐, 川又, 秋山君を始めとする芝浦工業大学, 東京大学の学生諸君に多大の協 力を頂いた。ここに記して謝意を表する。

\section{参考文献}

1)村川三郎，関根 毅ら：都市内河川が周辺の温熱環境に及ぼす効果に関する研究，日本建築学会計画系論 文報告集, Vol. 393,pp. 25-34,1988

2)村川三郎, 関根 毅ら：都市内河川が周辺の温熱環境に及ぼす効果に関する研究（続報）, 日本建築学会 計画系論文報告集, Vol. 415,pp. 9-19,1990

3)片山忠久ら：海岸都市における河川の暑熱緩和効果に関する調查研究，日本建築学会計画系論文報告集， Vol. 418,pp. 1-9, 1990

4)武若 聰, 池田駿介ら：都市河川が周辺地の気候に及ぼす効果, 環境システム研究, Vol. 20,pp. 33-40,1992

5) 北川 明ら：河川周辺の気候の快適性，土木技術資料，Vol. 31, No. 10,pp. 38-43,1989 